\title{
HISTORY
}

\section{THE IMAGE OF AN UKRAINIAN LECTURER AT THE TURN OF THE 2OTH - 21ST CENTURIES: EXPERIENCE HISTORICAL OF THE BEGINNING OF THE TRANSFORMATION OF THE EDUCATIONAL SYSTEM}

\author{
Cherevychnyi Gennadii Semenovich, Ph.D of Historical, in Education \\ The Department of Modern History Associate Professor, \\ National Taras Shevchenko University, Kyiv, Ukraine \\ ORCID: 0000-0001-9094-8732
}

\begin{abstract}
Rostoka Maryna Lvovna, Ph.D of Pedagogical, in Education, Senior Researcher, Department of Scientific Information and Analytical Support of Education, $V$. Sukhomlinsky State Scientific and Pedagogical Library of the National Academy of Pedagogical Sciences of Ukraine, Kyiv, Ukraine
\end{abstract}

ORCID: 0000-0002-1891-5482

DOI: https://doi.org/10.31435/rsglobal_ws/31012020/6902

\section{ARTICLE INFO}

Received: 21 November 2019

Accepted: 19 January 2020

Published: 31 January 2020

\section{KEYWORDS}

higher education system, teacher, university, national, transformation.

\begin{abstract}
The article unveils the teaching penalty against the background of the transformation of the higher education system of Ukraine at the end of the twentieth century - at the beginning of the twenty-first century, an attempt is made to present a holistic view of it from the point of view of the emotional and psychological state, motivation, and assessment of its consciousness. Information is also provided on external factors that have a direct impact on the effectiveness of the teaching environment. Its general quantitative and qualitative characteristics are also provided. It is concluded that the image of the Ukrainian teacher in the indicated period was determined by the state characteristic of a transitional society with the inertia of the manifestations of post-Soviet consciousness. This, in turn, determined their value series and motivation, which still often gravitated to the paradigm of the past. It turned out to be a permanent support group for the transformation of the higher education system - young teachers as natural carriers of innovation.
\end{abstract}

Citation: Cherevychnyi Gennadii Semenovich, Rostoka Maryna Lvovna. (2020) The Image of an Ukrainian Lecturer at the Turn of the 20th - 21st Centuries: Experience Historical of the Beginning of the Transformation of the Educational System. World Science. 1(53), Vol.2. doi: 10.31435/rsglobal_ws/31012020/6902

Copyright: (C) 2020 Cherevychnyi Gennadii Semenovich, Rostoka Maryna Lvovna. This is an openaccess article distributed under the terms of the Creative Commons Attribution License (CC BY). The use, distribution or reproduction in other forums is permitted, provided the original author(s) or licensor are credited and that the original publication in this journal is cited, in accordance with accepted academic practice. No use, distribution or reproduction is permitted which does not comply with these terms.

Introduction. The teacher in Ukraine was in the midst of change and challenges arising from the transformational processes inherent in the transitional societies. At the same time, when its function as a defender of popular interests was emphasized, a critical outlook on the actions of the authorities took place. The reasons for this were objective: civil society institutions have not yet been formed in the state. However, this potential was not effectively used by the then Ukrainian government. On the contrary, often the representatives of the scientific and pedagogical intelligency were driven out by it to a marginal position in society, and were discredited by the authorities. 
Although this particular social execution, according to the opinion of some researchers, should have helped to create a rule-of-law State with a corresponding manifestation of real civil rights and freedoms; should have counteracted the antisocial manifestations of the state and business; should have provided moral support to society and the promotion of its solidarity and consolidation of raising the level of consciousness of ordinary Ukrainians, paying attention to a decrease in both its and the cultural level in general. Moreover, it turned out that the state management system was sorely missed by people from the intellectual environment [11, p. 89; 2].

The teaching environment in Ukraine at that time was under the significant influence of external factors that determined the search for the optimal modernization model of the educational system in the country. Actually, as at the beginning of the twentieth century, the views of the Ukrainian intelligency were focused on the experience of the West in this area, in particular, of Western European countries. However, the difference between the beginning and the end of the twentieth century was that the transformation process took place to a certain extent in parallel with both the Western European higher education system and the Ukrainian one. Therefore, the need not only to adapt someone else's experience arose, but also to search for their effective innovations. At the same time, state educational institutions promoted the experience of developed countries and the corresponding models for the development of education without sufficient consideration for their critical analysis. It was at that time that the general stressful background increased, against which the teachers of educational institutions of Ukraine, in particular, universities, also carried out their activities. With a certain similarity of challenges to the system both in Ukraine and in the West, in particular: reduced state funding, the need to seek and attract additional funds, the important need to change the management of educational institutions, the structural diversification of the higher education system, the practical solution to these issues turned out to be different. In particular, in Ukraine at that time there was no change in the management of higher education institutions (hereinafter - the university), in particular: there was no replacement of the postSoviet managerial nomenclature with managers with an economic (way) method of thinking, for objective reasons - such people then has not yet been trained and formed within the system.

Analysis of Publications and Researches. The work of V.Z. huravsky «Higher Education as a State and Culture Factor in Ukraine» [3] is devoted to the coverage of the teacher's figure as a driving force for the implementation of state educational policy. A large amount of information allows to unveil various aspects of the activities of the scientific and pedagogical personnel of universities, including the legal framework, the economic basis of the higher education system, the conceptual foundations of the transformation processes of higher education in Ukraine, globalization influences and international cooperation collected in the work «The Scientific and Educational Potential of the Nation: a look in the XXI century» in 3 books authored by G. Sichkarenko [12]. The author illustrates a comprehensive approach to the analysis of higher education in Ukraine, its transformation, which, in particular, highlights the role of university teachers as a part of the country's intellectual layer in a transitional society. G. Sichkarenko managed to carry out structural and functional analysis of the system, which is undergoing its reform on the general modernization path of the state $[11 ; 12]$. A systematic analysis of higher education, a portrait description of its components - universities, including the management and teaching staff, with the provision of quantitative and qualitative indicators are given in the study «The Scientific and Educational Potential of Ukraine» [7].

It should be noted that in the 1990s a legal and regulatory framework is being created, in particular, the Law "On Education" (May 1991), according to which teachers carried out their professional activities [4]. Then an attempt was also made to develop a state strategy for the development of education - the State National Program «The Education» («Ukraine of the 21st Century») was introduced in November, 1993 [2].

Actually, in fact, we can monitor the influence of macro environment factors (political and legal) on the professional activities indicated by the social stratum. Creating a holistic vision / vision of the image of the teacher of that time is impossible without revealing the general position of the higher education system, its core are universities. In particular, it is worth focusing on the fact that its quantitative and qualitative changes have occurred, including structural differentiation both in terms of accreditation and degree. It was then that universities of the III-IV levels of accreditation (institutes, universities, academies) with state and non-state forms of ownership were formed. This information is illustrated in Figures 1 and 2, and the corresponding diagram (A, B) given below. The chart is compiled according to the Information-analytical review «The Education of Ukraine» [9, p. 63]. 


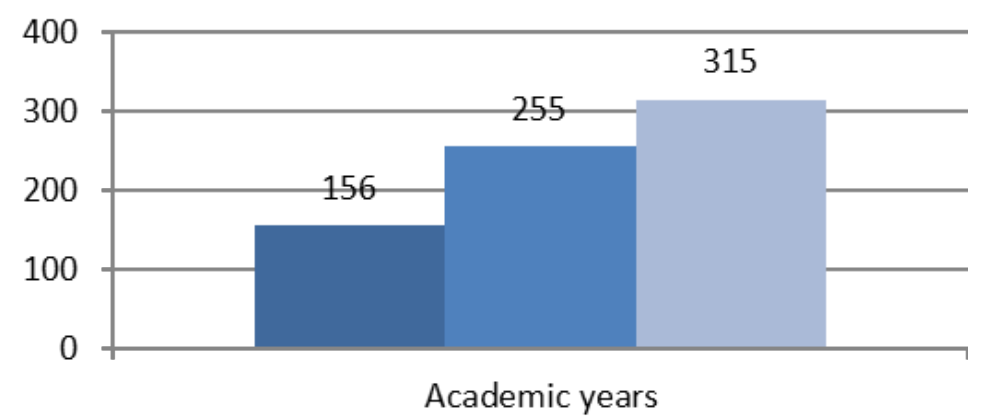

Fig. 1. A - The Quantitative Composition of Universities of the III-IV Levels of Accreditation

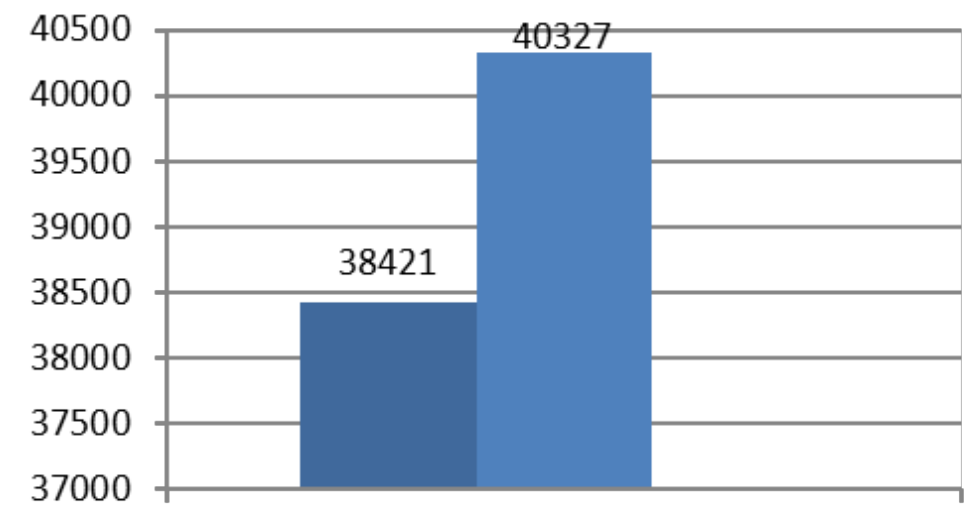

Academic years

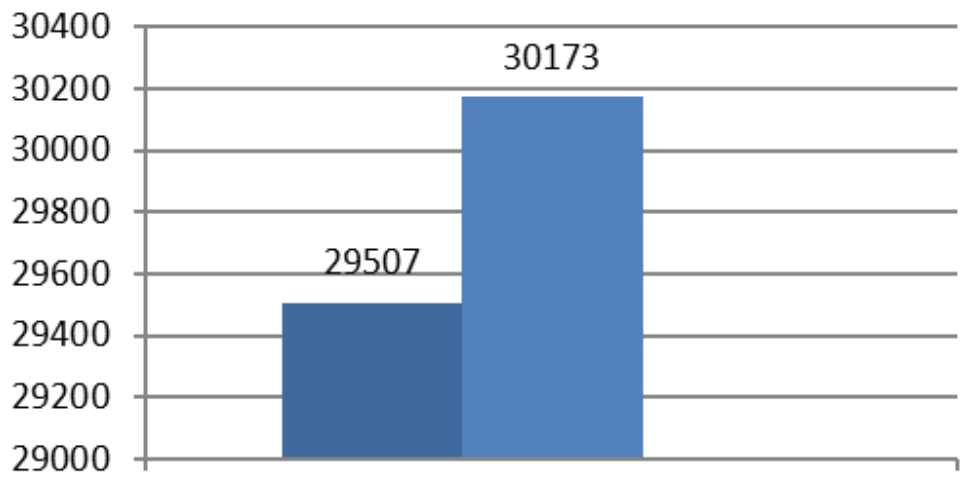

Academic years

Fig. 2. B-The Number of Candidates of Sciences

The diagram was compiled on the basis of the Information and Analytical Materials for the meeting of the final board of the Ministry of Education and Science on March 24, 2005 [1, p. 95].

As for the concretization of the growth dynamics of universities, the following should be noted: at the end of the twentieth century- at the beginning of the XXI century, a number of universities are being created in Ukraine: the National Academy of Management, Donetsk State Institute of Artificial Intelligence, the State Academy of Customs Service of Ukraine; National University Kiev-Mohyla Academy, Ostroh Academy, Chernihiv State Institute of Economics and Management and so on. Many of them will eventually emerge as leaders of national education, creating a new educational space. At the same time, the tradition of granting the status of a National University for outstanding scientific and educational achievements was begun. The status, in particular, was received by such well-known higher educational institutions in Ukraine as: Taras Shevchenko Kyiv State University, Kyiv Polytechnic Institute (now - National Technical University Kyiv Polytechnic Institute), Ukrainian State Medical University named after A. Bogomolets, Uzhgorod State University, as well as the Kyiv State Conservatory named after P.I. Tchaikovsky (now - P.I. Tchaikovsky National Music Academy of Ukraine) for, in particular, is a great success in training highly professional musicians - performers, scientific and scientific-pedagogical personnel, and many others [8, p. 137-139]. 


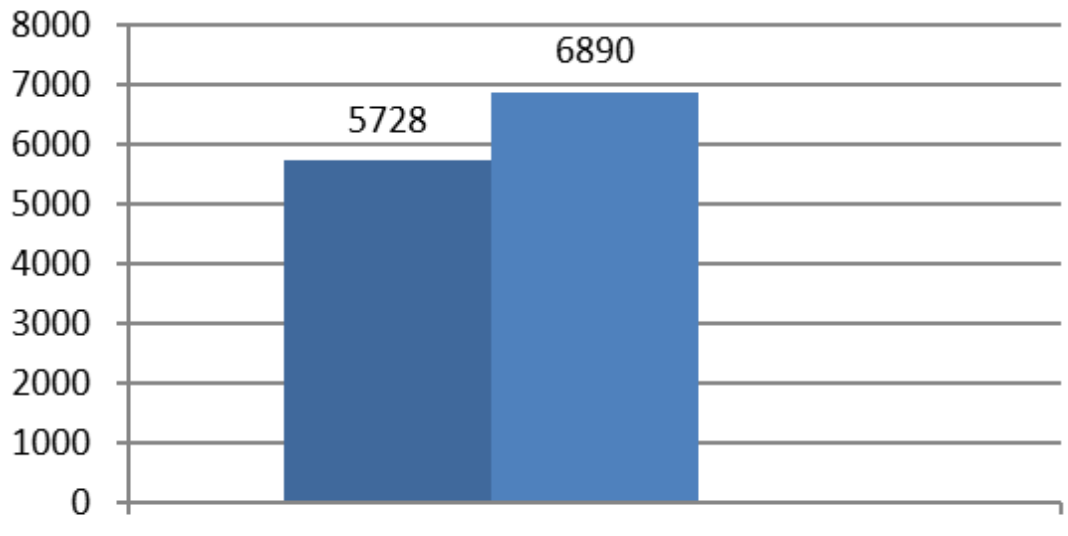

Academic years

1995/96 2000/01

Fig. 3. C-The Number of Doctors of Sciences

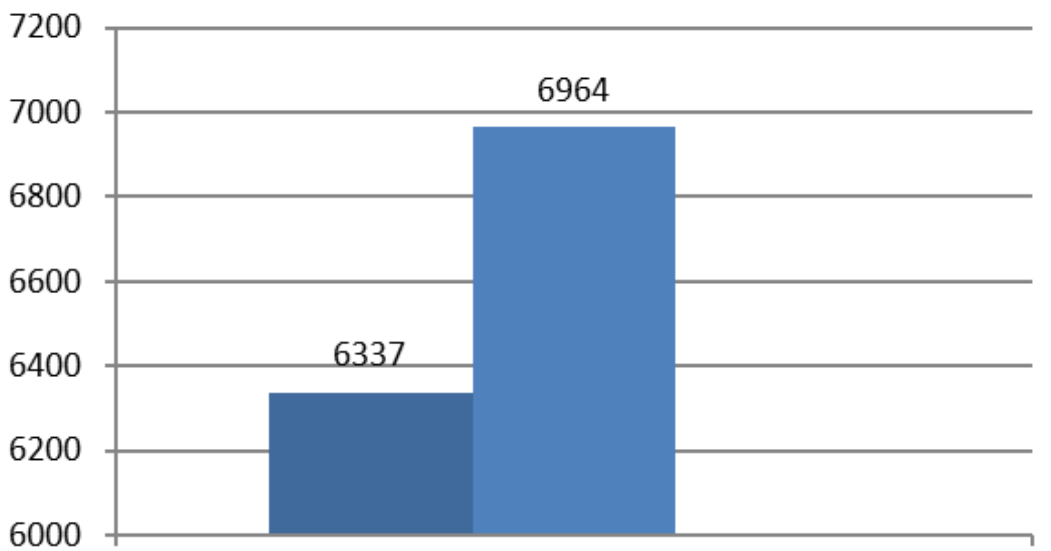

Academic years

1995/96 2000/01

Fig 4. D-The Number of Doctors of Sciences - Professors

The diagram was compiled on the basis of the information and analytical materials for the meeting of the final board of the Ministry of Education and Science of Ukraine on March 24, 2005 [1, P. 94]

It should also be noted that the government has attempted to provide growth dynamics of such important indicators characterizing the state of development of the education system (including higher education) as the index of the level of education in Ukraine and the index of human development associated with it. We managed to defeat the negative trends in the fall of the corresponding indicators since 1997. The country already had a certain growth dynamics, although, unfortunately, on the whole, these results allowed us to state only an average level. The traditional explanation for this was complaints about derivatives of the post-Soviet transformation, the transition economy inherent in this type of countries, which Ukraine also that time belonged to.

So, according to" The Human Development Report 2001", the educational level index in Ukraine was 0.92 . The place that the country occupied at that time in the overall ranking by the human development index was the 74th. It is worth noting that during the 90 s of the XX century its greatest decline was observed: in 1996 (0.701) compared with 1992 (0.762), but then still rose in 1999 (0.742) [9, pp. 19-20].

Probably, to display a holistic picture of the state of the educational system, in particular the higher one, there is a need to highlight the psycho-emotional state, value judgments, and motivation. Besides, there is an urgent need for a differentiated section of the post-Soviet society and teachers as a part of it, which differs from everything by the elements of the post-Soviet syndrome.

Monitoring the psycho-emotional characteristics of the teacher makes it possible to analyze the motivational direction of his activity as such; to understand the basics of the origins of the behavioral component in the educational process. Detection of this is successfully served by a poll that has a certain variability, in particular of the same post-Soviet consciousness, conducted in 2001 (May- 
June). It covered 25 universities in Kyiv, Kharkiv, Donetsk, Lutsk according to the methodology of interviewing teachers of different educational regions, as well as using the methodology of focus group interviews from representatives of the higher education system of various statuses (professional, official) in such cities as: Kyiv and Donetsk [5, p. 10].

It should be noted that teachers from both state and non-state universities passed polls. The assessment of the state of the then system of higher education by the teaching staff turned out to be rather critical: almost $2 / 3$ recognized the need for its change and only less than a quarter rated it positively [ibid., p. 13].

Even more revealing were the answers regarding the assessment of the past higher education system: more than half of those respondents at level III-IV higher education institutions rated it better than the modern one, more often teachers of state universities compared to non-state ones did it. Besides, the endorsement to the previous system was more shown by teachers of natural and technical specialties than humanitarian (the difference between them is from more than $3 / 4$ to slightly more than half among the respondents) [ibid., p.15].

Motivational factors, both tangible and intangible, are important components of the effective work of university teachers. Actually, the significance of the tangible aspect of their motivation was discovered. All respondents, regardless of age and qualification level, note in the range from half to $2 / 3$ the deterioration of their financial situation. Although, and this is worth noting, non-state universities are significantly fewer than those who complain of its deterioration; on the contrary, 2.5 times more than those who note its improvement. It is here that it should be noted that to assess their standard of living, they (teachers) took into account the increase in the number of students per teacher: more than $1 / 4$ for associate professors, more than $1 / 5$ for professors [Ibid., P. 18, 22].

Not the least is the existential manifestation of attitudes toward transformational processes in higher education. Generally, according to the results of the research, it turned out to be mostly positive: more than half with hope, almost every fifth with desire, only more than a tenth with distrust [Ibid., P. 50].

Sure, clarification of the perception of changes in the higher education system through the emergence of challenges and new opportunities became very important for understanding the motivational component of teachers' effectiveness. Actually, its success depends on a positive attitude towards the transformation of higher education. In general, the result of the poll was moderately encouraging: almost $2 / 5$ of the teachers perceived the changes as new opportunities for themselves, but a little more than $1 / 4$ as a threat. The age-related snapshot showed that young teachers see more prospects than others - almost half of the respondents. Representatives of private universities showed even better results - more than half of all [ibid., p. 52-53].

The moral and ethical component that characterizes the value orientations of teachers manifested itself in the course of this research as follows: more than half of the respondents showed their passive, conciliatory and explanatory attitude regarding profanity and corruption in higher education. It is worth adding that a similar position was more often chosen by representatives of state universities than non-state ones, as well as candidates of sciences in comparison with doctors [ibid., p. 162].

Conclusions. Making a resume, we can state the following: the image of an Ukrainian teacher at the end of the XX - beginning of the XXI century was in the direct content of transitional societies of the post-Soviet type, with their inherent manifestations of post-Soviet consciousness. Emotional and psychological characteristics, value orientations, in general, motivation in itself were still mostly in this paradigm. The main support group for the transformation of the higher education system turned out to be young teachers as natural carriers of innovation.

\section{REFERENCES}

1. Higher Education and Science are the Most Important Areas of Civil Society Responsibility and the Basis of Innovative Development. Kyiv, 2005, p. 95

2. State National Program «Education»: 21 st Century Ukraine; [Institute for Systems Research; resp. for the issue S.S. Pavlovsky]. Kyiv, 1994, p.62.

3. Zhuravsky V.S. Higher Education as a Factor of State and Culture in Ukraine. Kiev: «In-Yure» Publishing House, 2003, p. 41

4. The Law of Ukraine «On Education». Education. 2017 (September 05). URL: https://osvita.ua/legislation/law/2231/.

5. Kipen V.P., Korzhov T.O. University Teachers: a Sociological Portrait. Donetsk: Astro LLC. 2001, 198. p. 10.

6. The Scientific and Educational Potential of the Nation: a View in the 21st century; [collective authors: V. Litvin (group leader), V. Andrushchenko, S. Dovgy, etc.]. Kyiv: Navchalna Kniha, 2003. 
7. Scientific and Educational Potential of Ukraine; [Compiled by. L.M. Gavrilyuk]. Kyiv: LLC Ukrainian Rating, 2013. Vol. 3, p.240; illustrated.

8. Education of Ukraine During the Years of Independence: State, Facts, Events; [edited by V.G. Kremen]. Kyiv: Higher School, 2001, p. 137-139.

9. Education of Ukraine. Information and Analytical Review; [under the general editorship of V.G. Kremen. Kyiv: CJSC Nichlava, 2001. p. 19-20.

10. Sichkarenko G.G. The Intelligentsia in Post-Soviet Ukraine: Crisis of Identity (search for a social role). The Development Strategy of Ukraine (economy, sociology, law). Issue 5 (special issue) Kyiv: Knyzhkove Vydovnytstvo NAU, 2006, p. 181-187.

11. Sichkarenko G.G. Transformation of Higher Education in Independent Ukraine: [monograph]. Kyiv: Vydavnytstvo Tsentr KNAU, 2009, p. 89.

12. Sichkarenko G.G. The Historical Experience of the Restructuring of Higher Education in Ukraine (19852005): [monograph]. Nizhnin: Vydavets PE Lysenko M.M., 2014, p. 360. 